\title{
Glycemic Index of Traditional Meal (Dambu) from Pearl Millet and Maize
}

\author{
Maimuna Ladidi Aliyu ${ }^{1, ~ *, ~ S a f i y a ~ A l i y u ~ T i j j a n i ~}{ }^{1}$, Danladi Amodu Ameh², Aisha Babagana1 \\ ${ }^{1}$ Department of Nutrition and Dietetics, Kaduna Polytechnic, Kaduna, Nigeria \\ ${ }^{2}$ Department of Biochemistry, Ahmadu Bello University, Zaria, Nigeria
}

\section{Email address:}

maimunaba@yahoo.com (M. L. Aliyu), safiyaaliyutijjani@gmail.com (S. A. Tijjani), danladiameh@yahoo.co.uk (D. A. Ameh), babaganaaisha94@gmail.com (A. Babagana)

${ }^{*}$ Corresponding author

\section{To cite this article:}

Maimuna Ladidi Aliyu, Safiya Aliyu Tijjani, Danladi Amodu Ameh, Aisha Babagana. Glycemic Index of Traditional Meal (Dambu) from Pearl Millet and Maize. Science Journal of Analytical Chemistry. Vol. 8, No. 1, 2020, pp. 29-32. doi: 10.11648/j.sjac.20200801.15

Received: February 13, 2020; Accepted: February 25, 2020; Published: March 10, 2020

\begin{abstract}
The aim of this study is to determine the blood glucose response of traditionally prepared meal called Dambu from millet and maize enriched with beans, groundnut and vegetables. The cereals grains and other ingredients were purchased from a local market in Kaduna metropolis, and the preparation of the meal, blood glucose response with glycemic index method of determination used followed standard procedures. Result obtained indicated that product (Dambu) made from maize had higher $(5.2 \pm 0.8)$ blood glucose response among female subjects, while lowest $(5.14 \pm 0.53)$ blood glucose response value was recorded in subjects fed with product from millet. For the male subjects, the product made from millet had higher $(4.94 \pm 0.9)$ blood glucose response was recorded in subjects fed with products (Dambu) from maize. Both male and female subjects fed with product (Dambu) from maize had the lowest $(41.51 \%)$ and $(40.33 \%)$ glycemic index respectively. T-test was used to assess the sensory attributes of the products and the products were significantly different $(p<0.05)$. The product $(\mathrm{Dambu})$ from millet can be used for the management and control of diabetes as it showed low glycemic index and can also be used as healthy meal. Dambu from maize had the overall acceptability in flavor, taste, texture and colour, and it was the most preferred than dambu from millet.
\end{abstract}

Keywords: Glycemic Index, Millet, Maize, Blood Glucose Response, Kaduna

\section{Introduction}

The glycemic index (GI) is a classification of the blood glucose raising potential of carbohydrate foods. It is defined as the incremental area under the blood glucose response curve elicited by a $50 \mathrm{~g}$ available carbohydrate portion of a food expressed as a percentage of that after $50 \mathrm{~g}$ carbohydrate from a reference food taken by the same subject [1]. Many factors such as food forms, particle size, cooking and processing and starch structure effect the GI [2]. There is evidence that low GI foods improve blood glucose control in people with diabetes, reduce serum lipids in people with hypertriglyceridemia prolong endurance during physical activity [3].

However, application of the GI is made difficult because the GI value of many common foods is not known. In addition, the GI value reported by different laboratories vary widely for some food such as potato and rice [4]. Millets are one of the cereals asides the major wheat, rice and maize. Millets reduced the chance of type 2 diabetes, because of it significant level of magnesium found in the grain [5].

The prescription of wheat and beans based diet for diabetic management with the theory that wheat has lower glycemic index and beans is plant protein is common among diabetic patients. Thus diet diversity is important to enable patient have choice of other food or diet, therefore, there is need to determine the blood glucose response of traditionally prepared meal from millet and beans for the management of diabetes mellitus [6,7]. Hence this study was aimed at determining the blood glucose response of traditionally prepared meal from millet and maize enriched with beans, groundnut and vegetables. 


\section{Materials and Methods}

\subsection{Materials}

Millet (pearl millet) commonly called Gero in Hausa, Maize commonly called Masara in Hausa, beans (Black eye beans) commonly called wake in Hausa, groundnut and pumpkin leaves (ugu), moringa leaves and spinach leaves were purchased from the central market Kaduna.

\subsection{Procedure for Preparation}

The millet was sorted, then dehulled. The dehulled millet was winnowed and washed before drying and kept in an air tight container.

The beans were sorted, washed and kept in an air tight container, while the groundnut was also sorted, roasted, winnowed, coarse milled and kept in an air tight container. The moringa leaves, onion, red pepper and spring onion were also sorted, washed and cut then kept aside. The beans were poured into the boiling water and was allowed to boil, the millet was also poured and allowed to cook. The cooked millet, beans roasted pound nut and the pre-steamed moringa leaves, red pepper and onions and spring onions were mixed together. Seasoning and vegetable oil were also added to the mixed. It was then re steamed $\left(75^{\circ} \mathrm{C}-90^{\circ} \mathrm{C}\right)$ and was served [8].

\subsection{Determination of Blood Glucose Response}

Standard procedures as described by Jenkins was used to determine the blood glucose response of the products in the subjects [9].

\subsection{Glycemic Response Determination}

Glycemic Index (GI) was determined using a glucometer.

$$
\frac{\text { Glucose incremental level of the test food }}{\text { Glucose incremental level of the reference food }} \times 100
$$

$$
\mathrm{GI}=\frac{\mathrm{IAUC}}{\mathrm{IAUCS}} \times 100
$$

Where:

IAUC - incremental Area under the blood glucose response curve for the tasted meal

IAUCS - incremental Area under the blood glucose response curve for the standard meal [10].

\subsection{Sensory Evaluation}

Acceptability of the products was carried out by 20 semi trained panelists [11]. The panelist was selected among the research scholars and lecturers in the Department of Nutrition and Dietetics, Kaduna Polytechnic. A 9-point hedonic scale was used for sensory evaluation.

\section{Result and Discussion}

Table 1 indicates that there was significant difference $(p<0.05)$ in the blood glucose response of male subject fed with Dambu prepared from two samples (maize and millet). The subjects fed with product from millet had the highest value of $(4.94 \pm 0.9)$ while subjects fed with product from maize recorded the lowest $(4.82 \pm 0.64)$ value of blood glucose response.

Table 1. Mean value of blood glucose response of Dambu from maize and millet (Males).

\begin{tabular}{lll}
\hline Time & Maize & Millet \\
\hline Fasting & $4.7 \pm 0.21^{\mathrm{a}}$ & $4.9 \pm 0.91^{\mathrm{a}}$ \\
$30 \mathrm{mins}$ & $5.52 \pm 0.53^{\mathrm{a}}$ & $5.5 \pm 0.24^{\mathrm{a}}$ \\
$60 \mathrm{mins}$ & $4.92 \pm 0.62^{\mathrm{a}}$ & $5.06 \pm 1.16^{\mathrm{a}}$ \\
$90 \mathrm{mins}$ & $4.66 \pm 0.61^{\mathrm{a}}$ & $4.66 \pm 1.06^{\mathrm{a}}$ \\
$120 \mathrm{mins}$ & $4.3 \pm 0.58^{\mathrm{a}}$ & $4.56 \pm 0.91^{\mathrm{a}}$ \\
Total & $4.82 \pm 0.64^{\mathrm{a}}$ & $4.94 \pm 0.9^{\mathrm{a}}$ \\
\hline
\end{tabular}

Mean with different superscript within the same column are significantly different at $(\mathrm{P}<0.05)$

Table 2 shows that there was significant difference $(p<0.05)$ in the blood glucose of female subjects fed with dambu prepared from both samples (maize and millet). The blood glucose response was higher in the female subjects fed with product (dambu) from maize $(5.2 \pm 0.8)$. while product from millet had the lowest $(5.14 \pm 0.53)$.

Table 2. Mean value of blood glucose response of Dambu from maize and millet (Females).

\begin{tabular}{lll}
\hline Time & Maize & Millet \\
\hline Fasting & $5.06 \pm 0.5^{\mathrm{a}}$ & $5.04 \pm 0.27^{\mathrm{a}}$ \\
$30 \mathrm{mins}$ & $6.32 \pm 0.55^{\mathrm{a}}$ & $5.82 \pm 0.65^{\mathrm{a}}$ \\
$60 \mathrm{mins}$ & $5.3 \pm 0.6^{\mathrm{a}}$ & $5.1 \pm 0.31^{\mathrm{a}}$ \\
$90 \mathrm{mins}$ & $4.9 \pm 0.52^{\mathrm{a}}$ & $5.1 \pm 0.35^{\mathrm{a}}$ \\
$120 \mathrm{mins}$ & $4.42 \pm 0.4^{\mathrm{a}}$ & $4.64 \pm 0.21^{\mathrm{a}}$ \\
Total & $5.2 \pm 0.8^{\mathrm{a}}$ & $5.14 \pm 0.53^{\mathrm{a}}$ \\
\hline
\end{tabular}

Mean with different superscript within the same column are significantly different at $(\mathrm{P}<0.05)$

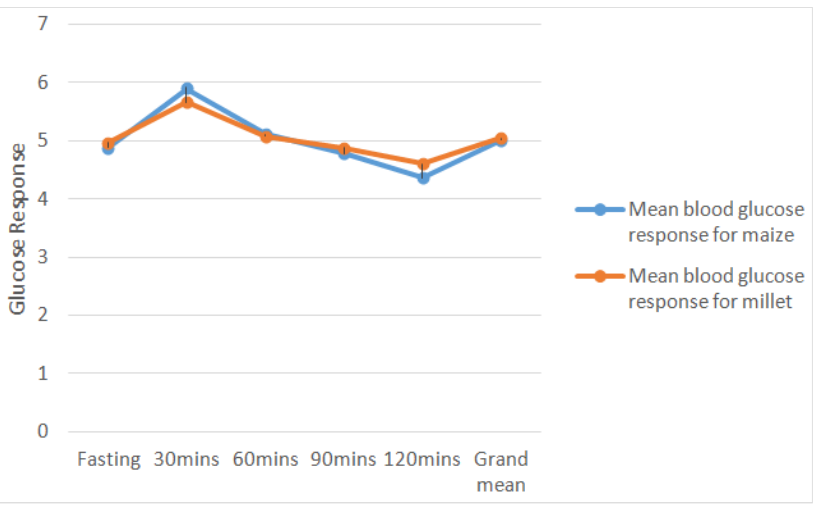

Figure 1. Blood Glucose Response of Dambu from Maize and Millet.

Table 3 shows the result of blood glucose response of all subjects (male and females) fed with products (dambu) from maize and millet. There was no significant difference $(p>0.05)$ in the average blood glucose response between subjects fed with product (dambu) from maize and millet at various time observed. However the grand mean indicated 
that product (dambu) from maize had the lowest $(5.01 \pm 0.74$ $\mathrm{mmol} / \mathrm{L}$ ) blood glucose response compared to dambu from millet $(5.04 \pm 0.74 \mathrm{mmol} / \mathrm{L})$.

Table 3. Mean value of blood glucose response of Maize and Millet.

\begin{tabular}{lll}
\hline Time & $\begin{array}{l}\text { Mean blood glucose } \\
\text { response for maize }\end{array}$ & $\begin{array}{l}\text { Mean blood glucose } \\
\text { response for millet }\end{array}$ \\
\hline Fasting & $4.88 \pm 0.41^{\mathrm{a}}$ & $4.97 \pm 0.64^{\mathrm{a}}$ \\
30mins & $5.92 \pm 0.66^{\mathrm{a}}$ & $5.66 \pm 0.49^{\mathrm{a}}$ \\
$60 \mathrm{mins}$ & $5.11 \pm 0.61^{\mathrm{a}}$ & $5.08 \pm 0.8^{\mathrm{a}}$ \\
$90 \mathrm{mins}$ & $4.78 \pm 0.55^{\mathrm{a}}$ & $4.88 \pm 0.78^{\mathrm{a}}$ \\
$120 \mathrm{mins}$ & $4.36 \pm 0.47^{\mathrm{a}}$ & $4.6 \pm 0.63^{\mathrm{a}}$ \\
Grand mean & $5.01 \pm 0.74^{\mathrm{a}}$ & $5.04 \pm 0.74^{\mathrm{a}}$ \\
\hline
\end{tabular}

Table 4 shows the glycemic index of product (dambu) prepared from maize and millet in both males and females subjects. The product (dambu) from millet had the higher glycemic index (44.83\%) and (44.31\%) in both the males and females respectively than maize dambu (40.33\%) and $(41.51 \%)$ with the males being higher than that of the females in millet while the females was higher in maize.

Table 4. Glycemic Index (\%) of Dambu from maize and millet by gender.

\begin{tabular}{lll}
\hline \multirow{2}{*}{ Food staples } & \multicolumn{2}{l}{ Glycemic Index (\%) } \\
\cline { 2 - 3 } & Male & Female \\
\hline Glucose (Food reference) & 100 & 100 \\
Dambu from Maize & 40.33 & 41.51 \\
Dambu from Millet & 44.83 & 44.31 \\
\hline
\end{tabular}

Table 5 indicate the sensory evaluation of products (dambu) prepared from maize and millet. Flavor ranged from $7.15 \pm 0.88$ to $7.35 \pm 1.09$ product (dambu) from millet had the lowest while the maize had the highest, this is expected as millet grain has a natural dark colour. The taste ranged from $7.10 \pm 1.12$ to $7.40 \pm 19$ with maize as most preferred and millet as the least preferred consistency texture, colour and overall acceptability ranged from $6.75 \pm 1.07$ to $6.90 \pm 1.12$ $7.10 \pm 0.91$ to $6.65 \pm 0.75,7.30 \pm 0.73$ to $7.35 \pm 0.81$ and $7.70 \pm 0.80$ to $7.5 \pm 1.00$ respectively with the parameters showing no significant difference $(\mathrm{p} \geq 0.05)$ amongst the samples.

Table 5. Mean Sensory Score of Dambu from Maize and Millet.

\begin{tabular}{llll}
\hline Sensory Parameter & $\begin{array}{l}\text { Dambu } \\
\text { (Maize) }\end{array}$ & $\begin{array}{l}\text { Dambu } \\
\text { (Millet) }\end{array}$ & P-values \\
\hline Flavour & $7.35 \pm 1.09^{\mathrm{a}}$ & $7.15 \pm 0.88^{\mathrm{a}}$ & .526 \\
Taste & $7.40 \pm 1.19^{\mathrm{a}}$ & $7.10 \pm 1.12^{\mathrm{a}}$ & .416 \\
Consistency & $6.75 \pm 1.07^{\mathrm{a}}$ & $6.90 \pm 1.12^{\mathrm{a}}$ & .667 \\
Texture & $7.10 \pm 0.91^{\mathrm{a}}$ & $6.65 \pm 0.75^{\mathrm{a}}$ & .096 \\
Colour & $7.30 \pm 0.73^{\mathrm{a}}$ & $7.35 \pm 0.81^{\mathrm{a}}$ & .839 \\
General Acceptability & $7.70 \pm 0.80^{\mathrm{a}}$ & $7.50 \pm 1.00^{\mathrm{a}}$ & .489 \\
\hline
\end{tabular}

Values are mean determination \pm standard deviation Means having different superscript in the same row are significantly different $(\mathrm{P}<0.05)$.

The study demonstrated that dambu reduced the blood glucose level in the subjects that were fed with the millet dambu after measuring their blood glucose at 30 minute interval for two hours and compared their fasting blood glucose level more than those fed with dambu made from maize, this indicated that millet has the rapecitic effect that have relevance in food dependent diseases such as diabetes this is in conformity with a study by Ohwovoriole [12] which stated that foods prepared from millets lowers blood glucose level in comparison to maize rice and wheat. Goni reported in a study that consumption of foods made from millets is associated with the reduced risk CVD and type 2 diabetes [13]. Both the products (Dambu) were of low blood glucose response and glycemic index maize and millet dambu $(44.83 \%)$ which signifies that the products were good for the management of diabetes with the varieties of vegetables added conductivity to the advantage as stated that consuming foods with low glycemic index helps to slow digestion and absorption to occur slowly resulting in low fluctuations in blood sugar level [14]. The sensory scores for color, taste, flavour, texture, consistency and general acceptability showed that sample A and sample B are significantly different $(p<0.05)$ sample A (Dambu) from maize was the most preferred in all sensory attributes $(p<0.05)$ except in consistency and color where sample B (Dambu) from millet had the highest score. Therefore, the nutrient quality of dambu from maize and dambu from millet and can be improved by adding groundnut and beans without affecting its acceptability [15].

\section{Conclusion}

The blood glucose response of subjects (males and females) fed with product (Dambu) from millet was higher compared to the subjects (males and females) fed with dambu which is lower. Both products showed low glycemic index and has overall acceptability in flavor, taste, texture and colour, and it was the most preferred than dambu from millet. Dambu can be used for the management and control of diabetes and can also be used as healthy meal. Further studies can be carried out on nutrient composition and microbial analysis of dambu from maize and millet.

\section{References}

[1] Wolever TMS, (1990). The glycaemic index. World Review of Nutrition and Dietetics. 62: 120-185.

[2] Hassan A, Elobeid T, Kerkadi A, (2010). Glycemic index of selected carbohydrate-based foods consumed in Qatar. International Journal of Food Science and Nutrition. 61 (5): 512-518.

[3] Jenkins DJA, Ghufari H, Wolever TMS, Taylor RH, Jenkins AL (2009). Relationship between rate of digestion of food and post prandial glycaemic. Diabetologia. 4 (2): 22-45.

[4] Agu HO, Anosike AN, Jideani IA (2008). Physicochemical and Microbial qualities of dambu produced from different cereal grains. Pakistan Journal of Nutrition 7 (1): 21-26.

[5] Ranawana DV, Henry CJK, Lightowler HJ, Wang D (2009). Glycaemic index of some commercially available rice and rice products in Great Britain. International Journal of Food Science and Nutrition. 60 Supply 4: 99-110. 
[6] Iken JE, Amusa NA, Obatolu VO (2002). Nutrient composition and weight evaluation of some newly developed maize varieties in Nigeria. The Journal of Food and Technology in Africa. 7 (1): 27-29.

[7] Alta MVA, Adeogun OA (1995) Nutrient and anti-nutrient components of some tropical leafy vegetables. Journal of Food Chemistry 53: 375-379.

[8] Agu HO, Anosike AN, Yusuf IZ, Jideani IA (2003). Physicochemical and sensory qualities of dambu produced from different cereal grains. Proceedings of the 27th Annual Conference/AGM of Nigerian Institute of Food Science and Technology (NIFST) held at Mambayya House Centre for Democratic Res. and Training Bayero University, Kano on 13th to 17 th October, 2003.

[9] Edo AE, Eregie A, Adediran OS, Ohwovoriole AE (2011). Glycaemic Response to some Commonly Eaten Fruits in Type 2 Diabetes Mellitus. West African Journal of Medicine. 30 (1): 94-98.

[10] Jongrungruangchok S, Bunrathep S, Songsak T (2010). Nutrients and mineral content of eleven different samples of moringa oleifera cultivated in Thailand. Journal Health Resources 24 (3): 123-127.

[11] Anjorin TS, Ikoko P, Okolo S (2010). Mineral composition of Moringa oleifera leaves, pods and seeds from two regions in Abuja, Nigeria. International Journal Agriculture and Biology. 12: 431-434.

[12] Ohwovoriole AE, Johnson. TO. (2009). Which Nigerian food for the diabetic? Nigerian Journal of Nutrition Science. 5: 5962 .

[13] Goni EK (2002). Effects of sodium tripolyphosphate, sorbitol, microbial, chemical and sensory quality of dambu kifi (A traditional Nigerian fish product). Bachelor of Science. Thesis, University of Maiduguri, Nigeria.

[14] Chen YJ, Sun FH, Wong SH, Huang YJ. (2010). Glycemic index and glycemic load of selected Chinese traditional foods. World Journal Gastroenterol. 16 (12): 1512-1517.

[15] Ali A, Al-Nassri HAS, Al-Rasasi B, (2010). Glycemic index and chemical composition of traditional Omani breads. International Journal Food Property. 13 (2): 198-208. 